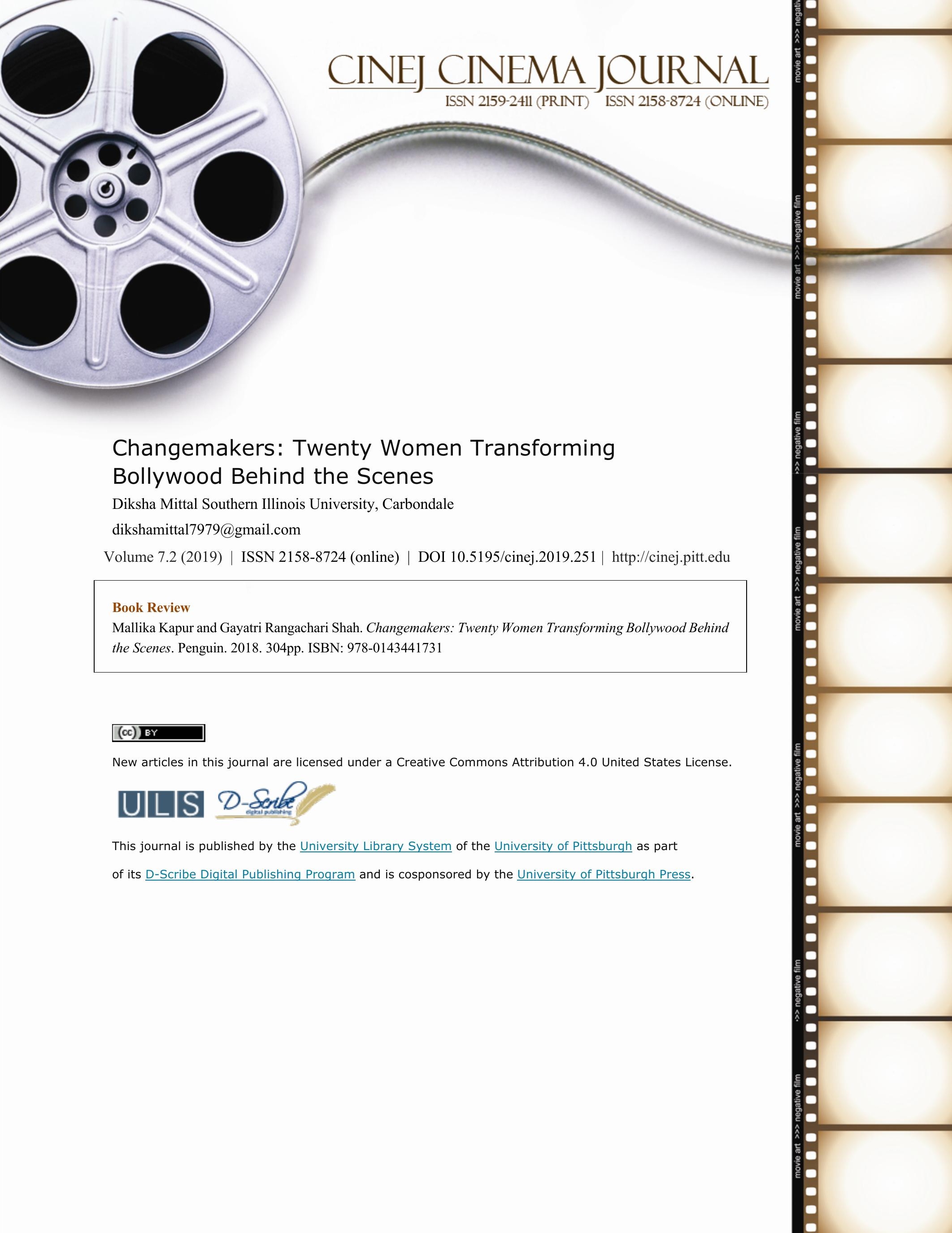




\section{Changemakers: Twenty Women Transforming Bollywood Behind the Scenes \\ Diksha Mittal}

Changemakers: Twenty Women Transforming Bollywood Behind the Scenes by Gayatri

Rangachari Shah and Mallika Kapur (2018) chronicles lives of twenty trailblazing women who

worked behind the scenes in the Bollywood industry and emerged as leaders in their respective

fields. It writes about their struggles with the prevalent gender bias and the unorganized nature of the backstage work in the industry post globalization of Bollywood in the 1990's. This is written by two mainstream Indian women print media journalists who extensively dug out lives of 20 such women and conducted 120 interviews through the course of one year.

The book cites the prestigious Geena Davis Institute on Gender in Media according to which the Indian film industry is characterized by 6.2 men to every women indicating the male dominated nature of the industry. It reflects on the struggles of women who wanted to make a mark in behind the scenes work in Bollywood which was dominated by men. The variety of women include the make-up artists, scriptwriters, stylists, film journalists, editors, directors, and choreographers some of whom have emerged to be well-known figures in television and cinema.

The book is a larger reflection on the status of women's employment and their socioeconomic and cultural position in India. In that sense, it is an achievement as it really digs deep 
into the factors that influenced the evolution and development of these modern women as feminists and that encouraged them to take pathbreaking careers. It gives an insight into the role of parenting during their childhood which gave them courage to choose their pathbreaking careers and later the role of Indian spirituality in helping them stick to their guns in difficult times. It is a unique take on the back stage roles in Bollywood as it throws light on the scattered nature of this work in a newly globalized film industry which was slow in becoming defined and broadening of scope as well as posed serious challenges to the entry of women at the turn of century.

The range of professionals included famous names like choreographer Geeta Kapur, director Farah Khan, producer Kiran Rao who have succeeded in changing the way people look at their profession and made it highly glamorous and attractive with the incoming of reality show television. In my opinion, the most intense fight was put up by the make-up artist Charu Khurana who emerged victorious against the courts after six years against an outrightly regressive 59 - year old ban which prohibited women to work as make-up artists in India for the fear of infringing on men's employment. In each chapter, the book discusses their personal stories and discusses how their presence slowly revolutionized the political economy of film industry and viewership as well as the employment sector in India. 
The book is a significant contribution to the field of feminist studies because it is one of the first to chronicle history of women behind the camera who have been ignored in the media and print literatures and connected it with the larger issue of women's rights and feminist movement in India. A common theme that run through the lives of all the 20 women was their tact in meandering their way through various roadblocks in their professional lives which constituted of intimidated men, suspicions regarding their talents, judgments on their dressing style and facing exclusion owing to being the only woman professional in their field. The other problems faced by women included outright sexual discrimination, wage gap, harassment and family troubles. Many of them tried to carve a unique niche and started an alternative cinematic trend in Bollywood. For instance, the producer Guneet Monga really tried to challenge the grand Bollywood stereotype of song and dance sequences and tried experimenting with different genres. The scriptwriter Juhi Chaturvedi brought in her own life experiences into the scripts she wrote for popular films thereby making the films about real life stories than simply grand escapist narratives. Their focus was on cinematically portraying the changing trends in a modernizing India was not only received well by the Indian film industry but also resulted in emboldening woman's voices in the Indian moviemaking post globalization. 
The well- known director Farah Khan, who was also one of the twenty women stated in the Foreword, "I would like men to read this book and realize that the women who work with them, and for them, go through a lot, and that they work much harder to get half the appreciation as men...I never talk about how many hits I have delivered and that nobody can push me around.. Women don't speak like that." Therefore, the book not only successfully brings out the hidden truth about the way men gaze at the handful of women in the industry but also on the intentional downplaying of themselves by silently achieve their goals without hurting men's egos. Though the book could have dealt with some of the life stories and anecdotes in greater detail to pique the reader's interest and closely tie the stories together, it does an impeccable job of drawing attention to the unsung women behind the hullabaloo of Bollywood. 